\title{
PERBANDINGAN TINGKAT NORMA KEBUGARAN JASMANI REMAJA USIA 16 - 19 TAHUN (USIA SMA) BERDASARKAN LETAK GEOGRAFIS
}

\author{
Rudi Aldiyanto a, Rima Febrianti,S.Pd.,M.Pd. ${ }^{b}$, Arif Rohman Hakim, S.Or., M.Pdc. \\ abc Physical Education, Universitas Tunas Pembangunan Surakarta, Surakarta, Indonesia. \\ Email :a aldiyantorudi@gmail.com
}

\section{N F O A R T I K E L}

Sejarah artikel:

Menerima 1 Januari 2021

Revisi 21 Januari 2021

Diterima 31

Online 1 Februari 2021

\section{Kata kunci:}

Norma Kebugaran Remaja ,

Dataran Rendah,

Dataran Tinggi.

Key words:

Adolescent Fitness Norms,

Lowlands, Highlands
Style APA dalam mensitasi artikel ini:

Rudi Aldiyanto (2021). Perbandingan Tingkat Norma Kebugaran Jasmani Remaja Usia 16 - 19 Tahun ( Usia SMA) Berdasarkan Letak Geografis (Jurnal Ilmiah Penjas),(Jurnal Ilmiah penjas) 7 (1) 1-12

\begin{abstract}
ABSTRAK
Tujuan dari penelitian ini adalah mengetahui perbandingan tingkat norma kebugaran jasmani pada remaja usia $16-19$ tahun (usia SMA) berdasarkan letak geografis. Jenis penelitian ini adalah penelitian perbandingan komparatif. Subyek dalam penelitian ini adalah remaja berusia 16 - 19 tahun di dataran tinggi dan remaja di dataran rendah. Metode penelitian terdiri dari tiga langkah, yaitu: (1) Observasi (2) Pengambilan data (3) Dokumentasi. Langkah-langkah pengambilan data sebagai berikut: Sprint, Pull up, Sit up, Vertical Jump, Lari jauh. Berdasarkan hasil analisis data sebagai berikut: Tingkat kebugaran sprint pada dataran rendah 3.6 sedangkan dataran tinggi 3.56. Tingkat kebugaran pull up dataran rendah nilai rata-rata sebesar 2.16 sedangkan dataran tinggi sebesar 2.52. Tingkat kebugaran sit up dataran rendah sebesar 2.76 sedangkan dataran tinggi sebesar 3 . Tingkat kebugaran vertical jump dataran rendah sebesar 2.84 sedangkan dataran tinggi sebesar 3.2. Tingkat kebugaran lari jauh dataran rendah sebesar 2.76 sedangkan dataran tinggi sebesar 2.80. Simpulan dari penelitian ini adalah Tingkat kebugaran secara keseluruhan kelompok dataran tinggi sedikit lebih baik yakni pada dataran rendah sebesar 14,12 sedangkan pada dataran tinggi sebesar 15,08. Pengujian statistik diperoleh kesimpulan bahwa tidak ada perbedaan signifikan antara kelompok dataran rendah dengan dataran tinggi. dengan nilai probabilitas (sig.) sebesar $0.070>0.05$.
\end{abstract}

Kata kunci : Norma Kebugaran Remaja, Dataran Rendah, Dataran Tinggi

\section{ABSTRACT}

The purpose of this study was to determine the comparison of the level of physical fitness norms in adolescents aged 16-19 years (high school age) based on geographical location. This type of research is a comparative research (comparative). The subjects used in this study were adolescents aged 16-19 years who lived in the highlands and adolescents who lived in the lowlands. This research method generally consists of three steps, namely: (1) Observation (2) Data collection (3) Documentation. The data collection steps are as follows: (1) Sprint (2) Pull up (3) Sit up (4) Vertical Jump (5) Long 
distance run. Based on the results of data analysis from the five aspects above as follows: The fitness level of the sprint aspect is almost the same, namely in the lowlands it is 3.6 while the highlands is 3.56 . The fitness level of the pullup aspect of the upland group tends to be better than the lowland group, namely in the lowlands the average value is 2.16 while in the highlands it is 2.52. The fitness level of the sit-up aspect of the upland group is slightly better than the lowland group, namely the lowland group of 2.76, while the highland aspect is 3. The fitness level of the vertical jump aspect is almost the same, namely in the lowlands of 2.84, while the upland is 3.2. The fitness level of the long running aspect is almost the same, namely in the lowlands it is 2.76 while in the highlands it is 2.80 . The conclusion of this study is that the overall fitness level of the upland group is slightly better, namely the lowland group is 14.12 while the highland group is 15.08. The statistical test concluded that in general there was no significant difference between the lowland and upland groups. Evidenced by the probability value (sig.) Of $0.070>0.05$.

Key words: Adolescent Fitness Norms, Lowlands, Highlands

\section{Pendahuluan}

Kesehatan merupakan salah satu faktor utama yang mempengaruhi kebugaran dan penampilan tubuh, serta harta yang paling berharga bagi manusia. Tidak ada kesehatan bisa dikatakan tidak ada kesempatan untuk menikmati kehidupan. Oleh karena itu setiap orang tentu menginginkan hidup sehat bahagia dan ingin selalu tampak sehat, bugar, penampilan yang bagus dan awet muda. Untuk menjaga kesehatan perlu adanya melakukan pola hidup sehat dimulai dengan menjaga pola makan yang sehat dan bergizi, porsi tidur atau istirahat juga harus cukup selain itu harus rajin berolahraga. Olahraga dan kesehatan merupakan kebutuhan bagi setiap orang, karena semua orang ingin sehat, tidak seorang pun yang ingin sakit atau pun terganggu dengan kesehatanya. UU No. 23 tahun 2009 pasal 1 ayat (1) Kesehatan adalah keadaan sehat, baik secara fisik, mental, spiritual maupun sosial yang memungkinkan setiap orang untuk hidup produktif secara sosial dan ekonomis. 
PERBANDINGAN TINGKAT NORMA KEBUGARAN JASMANI REMAJA USIA 16 - 19 TAHUN (USIA SMA) BERDASARKAN LETAK GEOGRAFIS

Rudi Aldiyanto, Rima Febrianti, Arif Rohman Hakim

Remaja yang memiliki tingkat kebugaran jasmani yang baik akan membantu penampilannya, meningkatkan produktivitas maupun prestasi belajarnya. Dengan mengacu pada tujuan tersebut maka sebagai indikator keberhasilan pendidikan jasmani remaja memiliki kesehatan dan kebugaran jasmani yang memadai, berperilaku baik, mampu mengendalikan mental emosional dan mampu menggunakan kapasitas intelektual secara optimal, sehingga akan terbentuk seorang siswa yang sehat, bugar, memiliki watak dan kepribadian, disiplin, sportif dan daya tahan yang tinggi. Sesuai dengan karakteristik remaja, kisaran umur 16-19 tahun kebanyakan dari mereka cenderung masih suka bermain dan masih terbawa suasana SMP. Untuk itu harus mampu mengembangkan pembelajaran yang efektif, disamping harus memahami usia tersebut seluruh aspek perkembangan manusia baik itu kognitif, psikomotor dan afektif mengalami perubahan. Perubahan yang mencolok adalah pertumbuhan dan perkembangan fisik dan psikologis. Seseorang dikatakan bugar ialah yang dapat melakukan atau melaksanakan aktifitas sehari hari tanpa mengalami kelelahan yang berarti sehingga tubuh masih memiliki cadangan energi untuk melakukan aktifitas tambahan. Kebugaran jasmani yang berkaitan dengan diri seorang remaja merupakan aspek penting yang harus dijaga. Untuk mempertahankan kebugaran jasmani, remaja dituntut untuk menjaga pola hidup sehat dimulai dengan menjaga pola makan yang sehat dan bergizi, porsi tidur atau istirahat juga harus cukup selain itu harus rajin berolahraga. Dengan begitu, remaja akan memiliki tingkat kebugaran jasmani yang tinggi dan dapat menggunakan pikiran dan tenaganya untuk semangat beraktifitas sekolah tanpa mengalami suatu kendala yang berarti. Tingkat kebugaran jasmani yang baik sangat dibutuhkan oleh setiap siswa. Melalui pendidikan jasmani dapat diharapkan siswa dapat memperoleh berbagai pengalaman untuk mengungkapkan kesan pribadi yang menyenangkan, kreatif, inovatif, terampil, meningkatkan dan memelihara kebugaran jasmani serta pemahaman terhadap gerak manusia. Serta tingkat 
kebugaran jasmani siswa tergantung pada aktivitas yang dilakukan oleh siswa diluar jam sekolah, serta media bermain pada siswa jaman modern sekarang kurang mengarah pada aktivitas fisik melainkan ke pasif dan media teknologi mengganti aktivitas fisik sehingga hilangnya kebudayaan di masyarakat tentang olahraga. Melihat kenyataan tersebut ternyata tingkat kebugaran jasmani masing-masing siswa berbeda beda dan bervariasi.

Berdasarkan pengamatan dan observasi yang dilakukan di lingkungan masyarakat dataran tinggi maupun rendah, dalam melakukan aktivitas olahraga remaja usia 16 - 19 tahun yang di dataran tinggi rata-rata mampu mengikuti aktivitas olahraga yang ada di lingkungan masyarakatnya dengan baik dan mampu melaksanakan pembelajaran jasmani di sekolah yang diberikan oleh guru, sedangkan siswa yang di dataran rendah dalam mengikuti aktivitas olahraga yang ada di lingkungan masyarakatnya rata-rata kurang antusias dikarenakan beberapa faktor, seperti kemajuan zaman yang menyebabkan banyak anak di dataran rendah lebih memilih untuk memainkan game online daripada melakukan aktivitas olahraga. Aktifitas masyarakat yang di lakukan di dataran tinggi dan dataran rendah, pada umumnya di dataran tinggi mayoritas masyarakatnya berprofesi sebagai petani, peternak atau juga buruh pemetik teh dan kopi, kondisi jalan yang belum rata serta jarak antar rumah yang satu dengan yang lain masih begitu jauh tidak seperti pada dataran rendah yang sudah rapat akan penduduk. Karena sudah ada kemajuan zaman, makanan yang dikonsumsi masyarakat di dataran tinggi dan di dataran rendah tidak memiliki perbedaan yang signifikan. Keseharian anak-anak di dataran tinggi lebih sering bermain permainan tradisional sedangkan remaja usia 16 - 19 tahun di dataran rendah lebih sering bermain game online. Di dataran tinggi remaja usia 16 - 19 tahun mayoritas menyukai kegiatan olahraga seperti bermain sepak bola, badminton dll sedangkan di dataran rendah remaja usia 16 - 19 tahun jarang yang mengikuti kegiatan olahraga seperti sepak bola, badminton, dan futsal. 
PERBANDINGAN TINGKAT NORMA KEBUGARAN JASMANI REMAJA USIA 16 - 19 TAHUN (USIA SMA) BERDASARKAN LETAK GEOGRAFIS

Rudi Aldiyanto, Rima Febrianti, Arif Rohman Hakim

Kebanyakan lebih memilih untuk menonton televisi dirumah, bermain game, atau hanya melihat saja tidak ikut dalam melakukan olahraga.

Kebugaran jasmani merupakan suatu konsep yang didalamnya mengandung komponen yang mendukung dan akan menggambarkan arti dari kebugaran jasmani. Kesegaran jasmani adalah bagian yang penting dari pertumbuhan dan perkembangan yang normal, namun definisi yang umum mengenai ketepatan sifat kesegaran jasmani belum pernah dapat diterima secara universal. Dijelaskan oleh Mulyono (2010: 57) Kesegaran jasmani adalah kemampuan seseorang untuk melakukan tugas fisik yang memerlukan kekuatan, daya tahan dan fleksibilitas. Kesegaran jasmani pada hakikatnya berhubungan dengan kemampuan dan kesanggupan fisik seseorang untuk melaksanakan tugas sehari-hari secara efisien dan efektif dalam waktu yang relatif lama tanpa menimbulkan kelelahan yang berarti, dan masih memiliki tenaga cadangan untuk melaksanakan aktivitas lainya. Nurhasan (2001: 132) menyatakan bahwa kesegaran jasmani adalah kesegaran fisik (physical fitnes), yakni : kemampuan untuk melakukan pekerjaan dengan efisien tanpa menimbulkan kelelahan yang berarti. Tidak menimbulkan kelelahan yang berarti disini maksudnya ialah setelah seseorang melakukan sesuatu kegiatan atau aktivitas, tubuh masih mampu dan mempunyai cukup semangat dan tenaga untuk menikmati waktu senggangnya dan masih sanggup untuk melakukan aktivitas lainnya yang mendadak.

Kesimpulannya kesehatan jasmani sangatlah penting bagi setiap manusia karena tanpa mempunyai kesehatan maka manusia itu sendiri akan kesulitan dalam melakukan pekerjaan dan beraktifitas yang lebih. Kesegaran jasmani merupakan modal dasar bagi setiap manusia untuk dapat melakukan serangkaian aktivitas sehari harinya. Berdasarkan beberapa uraian di atas dapat disimpulkan bahwa yang dimaksud dengan kesegaran jasmani adalah kemampuan atau daya tahan tubuh 
seseorang untuk melakukan pekerjaan atau aktivitas sehari-harinya secara efisien tanpa menimbulkan kelelahan yang berarti dan masih mempunyai cadangan energi untuk melakukan aktivitas lainnya yang mendesak.

Menurut Untung (2015: 177) "Tes Kesegaran Jasmani Indonesia" (TKJI) telah disepakati dan ditetapkan menjadi instrumen/alat tes yang berlaku di seluruh wilayah indonesia karena TKJI disusun dan disesuaikan dengan kondisi anak-anak indonesia. TKJI dibagi dalam 4 kelompok usia, yaitu : 6-9 tahun, 10-12 tahun, 13-15 tahun, dan 16-19 tahun. Akan tetapi pada handout ini akan dibahas 16-19 tahun. Menurut Nurhasan (2001: 135) tes kesegaran jasmani indonesia terdiri dari 5 butir tes, dengan rangkaian tes, yaitu:
a. Lari cepat (dash/sprint)
b. Angkat tubuh (pull-up)
c. Baring duduk (sit-up)
d. Loncat tegak (vertical jump)
e. Lari jauh

Menurut Untung $(2015,177)$ Tes Kesegaran Jasmani Indonesia, dibagi menjadi 4 kelompok usia, yaitu : 6-9 tahun, 10-12 tahun, 13-15 tahun, dan 16-19 tahun. Mengkaji dari beberapa pendapat tentang Tes Kesegaran Jasmani Indonesia jadi dapat disimpulkan bahwa TKJI dapat digunakan untuk siswa Sekolah Dasar, siswa Sekolah Menengah Tingkat Pertama dan remaja yang seusia, dan Sekolah Menengah Tingkat Atas dan remaja yang seusia.

Letak geografis adalah letak suatu daerah dilihat dari kenyataanya di bumi atau posisi daerah itu pada bola bumi dibandingkan dengan posisi daerah lain. Letak geografis ditentukan pula oleh segi astronomis, geologis, fisiografis, dan sosial budaya. Dataran rendah di Indonesia umumnya terjadi dari hasil sedimentasi sungai. Dataran rendah juga disebut dataran aluvial. Dataran aluvial biasanya berhadapan dengan pantai landai laut dangkal. Dataran ini biasanya tanahnya subur, sehingga lebih padat dibandingkan dengan daerah pegunungan. Dataran Jurnal IImiah Penjas, ISSN : 2442-3874 Vol 7. No.1 Januari, 2021 
PERBANDINGAN TINGKAT NORMA KEBUGARAN JASMANI REMAJA USIA 16 - 19 TAHUN (USIA SMA) BERDASARKAN LETAK GEOGRAFIS

Rudi Aldiyanto, Rima Febrianti, Arif Rohman Hakim

rendah adalah hamparan luas tanah dengan tingkat ketinggian yang diukur dari permukaan laut adalah relatif rendah (sampai dengan $200 \mathrm{mdpl}$ ). Dataran tinggi yaitu dataran luas yang letaknya diantara 100 sampai 800 meter diatas permukaan laut. Dataran tinggi adalah dataran luas yang terletak di daerah tinggi atau pegunungan maka disebut dataran tinggi. Dataran tinggi terbentuk dari hasil erosi dan sedimentasi. Dataran tinggi disebut juga plato (plateu).

Menurut Choirul Hadi (2012: 2) Norma merupakan rata-rata atau kekhasan pada tes tertentu yang dibuat berdasarkan spesifikasi populasi, misalnya rata-rata skor tes intelegensi pada kelompok anak yang berusia 16 tahun. Berdasarkan beberapa uraian diatas dapat disimpulkan bahwa norma adalah nilai rata-rata dari suatu tes kelompok tertentu yang digunakan sebagai acuan untuk memberikan makna pada skor-skor individu. Untuk itu, norma yang telah diperoleh dari beberapa klasifikasi yang hampir sama, dimaksudkan untuk tujuan yang sama belum tentu bisa dibandingkan. Informasi ini sangat penting untuk menentukan apakah instrumen tersebut tepat dalam situasi tertentu atau tidak.

Menurut Nindy (2010: 3-4) terdapat dua macam norma yaitu pendekatan penilaian yang membandingkan hasil pengukuran seseorang dengan hasil pengukuran yang diperoleh orangorang lain dalam kelompoknya, atau dapat disebut dengan Penilaian Acuan Norma (Norm - Refeereced Evaluation) dan pendekatan penilaian yang membanding hasil pengukuran dengan "batas yang ditetapkan, dinamakan dengan Penilaian Acuan Patokan (Criterian refenced Evaluation). Berdasarkan urian diatas peneliti menggunakan acuan norma Pendekatan Acuan Norma (PAN)

\section{Metode}

Penelitian ini merupakan penelitian non eksperimen melalui pendekatan deskriptif kuantitatif. Desain penelitian yang digunakan adalah desain komparatif, 
yaitu penelitian diarahkan untuk membandingkan satu kelompok sample dengan kelompok sample yang lainnya. Penelitian ini dilakukan untuk membandingkan tingkat norma kesegaran jasmani untuk remaja usia 16 - 19 tahun, dengan menggunakan teknik tes dan pengukuran.

Untuk memudahkan peneliti dalam melakukan penelitian, maka dibuatlah alur peneltian yang mana dimulai dengan observasi kepada perangkat desa dan keadaan lingkungan desa kemudian dilanjutkan dengan pengambilan data dengan menggunakan formulir tes dan pengambilan dokumentasi. Setelah data terkumpul lalu dikelompokkan secara menyeluruh kemudian data tersebut diolah dan dianalis guna untuk mendapatkan hasil berupa kesimpulan dari penelitian tersebut.

\section{Hasil Dan Pembahasan}

1. Sprint

Tingkat kebugaran Sprint letak geografis dataran rendah diperoleh rata-rata Sprint sebesar 3.60 dengan standar deviasi sebesar 0.91287 Sprint terkecil pada letak geografis dataran rendah sebesar 2 dan yang terbesar sebesar 5. Tingkat kebugaran Sprint letak geografis dataran tinggi diperoleh rata-rata Sprint sebesar 3.56 dengan standar deviasi sebesar 0.71181 Sprint terkecil pada letak geografis dataran tinggi sebesar 2 dan yang terbesar sebesar 5 .

2. Pull Up

Tingkat kebugaran Pull Up letak geografis dataran rendah diperoleh rata-rata Pull Up sebesar 2.16 dengan standar deviasi sebesar 0.89815 Pull Up terkecil pada letak geografis dataran rendah sebesar 1 dan yang terbesar sebesar 4 . Tingkat kebugaran Pull Up letak geografis dataran tinggi diperoleh rata-rata Pull Up sebesar 2.52 dengan standar deviasi sebesar 0.65320 Pull Up terkecil pada letak geografis dataran tinggi sebesar 2 dan yang terbesar sebesar 4 .

3. Sit Up

Tingkat kebugaran Sit Up letak geografis dataran rendah diperoleh rata-rata Sit Up sebesar 2.76 dengan standar deviasi sebesar 0.59722 Sit Up terkecil pada 
PERBANDINGAN TINGKAT NORMA KEBUGARAN JASMANI REMAJA USIA 16 - 19 TAHUN (USIA SMA) BERDASARKAN LETAK GEOGRAFIS

Rudi Aldiyanto, Rima Febrianti, Arif Rohman Hakim

letak geografis dataran rendah sebesar 2 dan yang terbesar sebesar 4 . Tingkat kebugaran Sit Up letak geografis dataran tinggi diperoleh rata-rata Sit Up sebesar 3 dengan standar deviasi sebesar 0.50000 Sit Up terkecil pada letak geografis dataran tinggi sebesar 2 dan yang terbesar sebesar 4 .

4. Vertical Jump

Tingkat kebugaran Vertical jump letak geografis dataran rendah diperoleh ratarata Vertical jump sebesar 2,84 dengan standar deviasi sebesar 0.85049 Vertical jump terkecil pada letak geografis dataran rendah sebesar 2 dan yang terbesar sebesar 4. Tingkat kebugaran Vertical jump letak geografis dataran tinggi diperoleh rata-rata Vertical jump sebesar 3 dengan standar deviasi sebesar 0. Vertical jump pada letak geografis dataran tinggi keseluruhan sebesar 3.

5. Lari Jauh

Tingkat kebugaran Lari jauh letak geografis dataran rendah diperoleh rata-rata Lari jauh sebesar 2.8 dengan standar deviasi sebesar 0.707 Lari jauh terkecil pada letak geografis dataran rendah sebesar 2 dan yang terbesar sebesar 4 . Tingkat kebugaran Lari jauh letak geografis dataran tinggi diperoleh rata-rata Lari jauh sebesar 2 dengan standar deviasi sebesar 0. Lari jauh keseluruhan pada letak geografis dataran tinggi sebesar 2.

Berdasarkan hasil uji data dengan teknik shapiro wilk dapat diketahui bahwa nilai $p$ (sig) pada kelompok dataran rendah sebesar 0.179 sedangkan pada dataran tinggi diperoleh nilai sebesar 0.014 . hal ini berarti data tingkat kebugaran pada dataran rendah berdistribusi normal sedangkan pada dataran tinggi tidak berdistribusi normal. Karena uji normalitas tidak terpenuhi maka uji statistik yang digunakan bukan uji t tetapi uji laternatif yakni statistik nonparametric mann whitney. 


\begin{tabular}{|l|r|r|r|l|}
\hline \multirow{2}{*}{} & \multicolumn{3}{|c|}{ Shapiro-Wilk } & \multirow{2}{*}{ Kesimpulan } \\
\cline { 2 - 4 } & Statistic & \multicolumn{1}{|c|}{$\mathrm{df}$} & \multicolumn{1}{|c|}{ Sig. } & \\
\hline Dataran &, 944 & 25 &, 179 & Normal \\
Rendah &, 894 & 25 &, 014 & Tidak Normal \\
Dataran & & & & \\
\hline Tinggi & & & & \\
\hline
\end{tabular}

Tabel 1.

Karena data tidak berdistribusi normal maka uji statistik uji $\mathrm{t}$ tidak dapat dilakukan. Untuk mengatasinya dilakukan uji statistik nonparametrik mann whitney. Uji statistik mann whitney tidak memerlukan syarat data harus berdistribusi normal maupun homogen. Sehingga uji asumsi normalitas dan homogenitas tidak diperlukan. Untuk mengetahui apakah terjadi peningkatan signifikan antara kelompok dataran rendah dan dataran tinggi metode digunakan statistik nonparametrik mann whitney. Hasil perhitungan sebagai berikut :

Tabel 2.

\section{Ranks}

\begin{tabular}{|l|l|r|r|r|}
\hline & & & & \\
& Kelas & N & Mean Rank & Sum of Ranks \\
\hline & & & & \\
\hline Hasil & Dataran Rendah & 25 & 21,84 & 546,00 \\
& Dataran Tinggi & 25 & 29,16 & 729,00 \\
& Total & 50 & & \\
\hline
\end{tabular}

Test Statistics ${ }^{\mathrm{a}}$

\begin{tabular}{|l|r|}
\hline & \multicolumn{1}{|c|}{ Hasil } \\
\hline Mann-Whitney U & 221,000 \\
Wilcoxon W & 546,000 \\
Z & $-1,811$ \\
Asymp. Sig. (2-tailed) &, 070 \\
\hline
\end{tabular}


PERBANDINGAN TINGKAT NORMA KEBUGARAN JASMANI REMAJA USIA 16 - 19 TAHUN (USIA SMA) BERDASARKAN LETAK GEOGRAFIS

Rudi Aldiyanto, Rima Febrianti, Arif Rohman Hakim

Pengambilan keputusan :

Apabila sig $\geq 0,05$ maka Ho di terima (tidak ada perbedaan signifikan kelompok dataran rendah dan dataran tinggi). Apabila sig < 0,05 maka Ho di tolak (ada perbedaan signifikan kelompok dataran rendah dan dataran tinggi).

Probalitas/Sig sebesar 0,070. Karena probalitas/sig $\geq 0,05$ maka Ho diterima. yang artinya tidak ada perbedaan signifikan kelompok dataran rendah dan dataran tinggi.

\section{Simpulan}

Berdasarkan penelitian di lakukan oleh peneliti dapat di simpulkan sebagai berikut: Dalam tes kebugaran jasmani di dataran tinggi diketahui bahwa remaja yang termasuk kategori baik sekali 0 remaja, baik 2 remaja, cukup 22 remaja, kurang 1 remaja, kurang sekali 0 remaja, jadi dapat di kategorikan cukup. Sedangkan, tes kebugaran jasmani di dataran rendah di ketahui bahwa remaja yang termasuk kategori baik sekali 0 remaja, baik 4 remaja, cukup 10 remaja, kurang 10 remaja, kurang sekali 1 remaja, jadi dapat di kategorikan cukup.

Tingkat kebugaran aspek sprint hampir sama yakni pada dataran rendah sebesar 3,60 sedangkan pada dataran tinggi sebesar 3,56. Tingkat kebugaran aspek pull up kelompok dataran tinggi cenderung lebih baik dibandingkan kelompok dataran rendah yakni pada dataran rendah nilai rata-rata sebesar 2,16 sedangkan pada dataran tinggi sebesar 2,52. Tingkat kebugaran aspek sit up kelompok dataran tinggi sedikit lebih baik dibandingklan kelompok dataran rendah yakni pada dataran rendah sebesar 2,76 sedangkan pada dataran tinggi sebesar 3,00. Tingkat kebugaran aspek vertical jump hampir sama yakni pada dataran rendah sebesar 3,84 sedangkan pada dataran tinggi sebesar 3,00. Tingkat kebugaran aspek lari jauh hampir sama yakni pada dataran rendah sebesar 2,80 sedangkan pada dataran tinggi sebesar 2,00 . 
Tingkat kebugaran secara keseluruhan kelompok dataran tinggi sedikit lebih baik yakni pada dataran rendah sebesar 14,12 sedangkan pada dataran tinggi sebesar 15,08. Pengujian secara statistik diperoleh kesimpulan bahwa secara umum tidak ada perbedaan signifkan antara kelompok dataran rendah dengan dataran tinggi. Dibuktikan dengan nilai probabilitas (sig.) sebesar $0.070>0.05$.

\section{Ucapan Terimakasih}

Saya sampaikan terimakasih kepada masyarakat desa Keposong dan desa Banmati khususnya remaja usia 16 -19 tahun yang telah bersedia menjadi sampel dalam penelitian ini, ucapan yang sama juga saya ucapkan kepada pimpinan khususnya bapak Dekan FKIP dan Kaprodi Penjas yang telah mendukung peneitian ini sehingga dapat berjalan dengan baik dan lancar, semoga penelitian ini dapat bermanfaat bagi seluruh masyarakat.

\section{Referensi}

Choirul Hadi. 2012. Pengertian Norma Pengukuran. http://choliculfpsi.web.unair.ac.id/artikeldetail-40669-pengukuran\%20kinerja-Norma.html. Diakses pada tanggal 17 Desember 2017, pukul 12.20 WIB.

Mulyono Biyakto Atmojo. 2010. Tes dan Pengukuran Pendidikan Jasmani / Olahraga. Surakarta: UNS Perss.

Nindy. 2010. Tes Kesegaran Jasmani Indonesia. Jakarta: Pusat Pengembangan kualitas jasmani.

Nugroho Untung. 2015. Pedoman Tes Ukur Olahraga. Grobogan: CV. Sarnu Untung.

Nurhasan. 2001. Tes dan pengukuran dalam pendidikan jasmani. Jakarta: Depdiknas. Undang-Undang RI Nomor 23 tahun 2009 pasal 1 ayat (1) Tentang Kesehatan. 
